\title{
LUZ, PALCO E A CARACTERIZAÇÃO DE TRADUTORES E INTÉRPRETES DE LIBRAS- PORTUGUÊS EM UMA PEÇA TEATRAL
}

\author{
LIGHTS, STA GE AND THE \\ CHARACTERIZATION OF SIGN LANGUAGE- \\ PORTUGUESE TRANSLATOR/INTERPRETER \\ ON ATHEATER PLAY
}

\author{
Neiva de Aquino Albres \\ Universidade Federal de Santa Catarina, UFSC, Florianópolis, SC, Brasil \\ Wharlley dos Santos \\ Universidade Federal de Santa Catarina, UFSC, Florianópolis, SC, Brasil
}

\begin{abstract}
Resumo: Neste artigo descreve-se um caso de caracterização de tradutor-intérprete de língua de sinais em peça teatral, contribuindo para a compreensão desse tipo de atuação e das formas de produçáo de sentido e efeitos de sentido em espetáculo teatral. Toma-se como base autores dos estudos da tradução e interpretação (PÖCHHACKER, 2004, 2015) e estudos linguísticos, principalmente, em uma perspectiva dialógica da linguagem (BAKHTIN; VOLOCHINOV, 1997). Desenvolve-se um estudo de caso com base em documentos da peça "X-QUEM? Origens”. Utiliza-se do roteiro, fotos e artefatos; analisa-se a presença de palco, a caracterização e a iluminação no tradutor-intérprete. Evidencia-se o diálogo entre a dimensão linguística da tradução e interpretação e a imagem, ou seja, como vê-se o corpo do tradutor em cena, discutindo-se sobre os aspectos de figurino, maquiagem, posicionamento e articulaçáo com os personagens da peça teatral.
\end{abstract}

Palavras-chave: Interpretação simultânea artística; Esfera Teatral; Tradução e interpretação de línguas de sinais; Figurino; Maquiagem.

Abstract: This article describes the characterization of the Sign Language Translator/Interpreter on a theater play, with the objective of contributing to the i) comprehension of this type of work and ii) the different ways of producing sense and effects within the theatrical performance. We used the theoretical support of the Translation and Interpreting Studies (PÖCHHACKER, 2004, 2015) and Linguistic Studies, focusing on a dialogic perspective of language (BAKHTIN; VOLOCHINOV, 1997). We develop a case study based on the documents from the play "X-QUEM? - Origens". We use the script, some pictures, and artifacts; and we analyze the stage presence, the characterization and the lighting on the translator/interpreter. We also highlight the relationship between the linguistic dimension of the translating/interpreting process and the image, that is, how the translator's body is seen when on stage; discussing aspects such as 
costume, make-up, positioning and the articulation with the characters from the play.

Keywords: Simultaneous Artistic Interpreting; Theatrical Context; Sign Language Translation and Interpreting; Costume; Make-up.

\section{Introduçáo}

Em qualquer comunicação humana, construímos sentidos para além do código linguístico, tanto em comunicaçóes face a face como em meios impressos ou digitais, tais como: texto, imagem, cores, designs, posturas, entre outros aspectos que contribuem para a construção da significação. Esse fenômeno multimodal também acontece com o público que assiste a uma peça teatral em que co-ocorrem muitas informaçóes no momento do espetáculo. Concordamos que a tradução e interpretação de peça teatral demandam assumir a existência dessa esfera como um gênero discursivo com características específicas, que devem ser conhecidas pelo profissional tradutor e intérprete de Libras-português - TILSP (FOMIN, 2018b). A partir de estudos de Bakhtin e do Círculo, sob uma perspectiva dialógica, que concebe a linguagem como um processo de interação construído por meio da história e das diferentes ideologias vividas em situaçóes reais, desenvolvemos, neste artigo, a análise de uma peça teatral interpretada simultaneamente em espetáculo que fez uso de palco, luzes e performance dos artistas ao mesmo tempo da atuação do tradutor-intérprete de Librasportuguês.

Em um processo de tradução e interpretação, tem-se um texto de partida e um texto de chegada, como também sujeitos envolvidos; o locutor e o interlocutor. Projetos discursivos, expectativas e construçáo de sentidos perpassam pelo cunho valorativo de todos os envolvidos no ato comunicativo (SOBRAL, 2008). Posto isso, em uma peça teatral, o espectador espera assistir a uma encenaçáo que, geralmente, envolve diferentes personagens, enredo e projeto completo de cenas, que desencadeiam um envolvimento discursivo. Contudo, em um processo de traduçáo e interpretação, por vezes, todo esse complexo processo passa pelas mãos de um único profissional, o tradutor-intérprete de Libras-português, que fica apartado do espetáculo.

Pela recente inclusão da Libras e da acessibilidade para a comunidade surda (BRASIL, 2002, 2015) ${ }^{1}$ e pelo seu caráter de novidade no campo

${ }^{1}$ No Brasil há um arcabouço legal que sustenta a acessibilidade em Libras à educação, saúde, cultura entre outros bens sociais para a comunidade surda. Tem seu alicerce no reconhecimento da Língua Brasileira de Sinais em 2002 e no Estatuto da Pessoa com Deficiência em 2015 entre 
artístico-cultural, normalmente, os tradutores-intérpretes são colocados de lado e são orientados a aparecer o menos possível para não "interferir" na obra (RICHARDSON, 2016). Essa é a concepção que se tem, tradicionalmente, de TILSP em peças teatrais. Mais recentemente, temos percebido algumas inovações na colocação do TILSP, em posiçóes mais centrais, nas suas interaçôes com o elenco, como também na sua caracterização com figurino e maquiagem específicos, como indicado por Fomin (2018a).

Os processos de tradução e interpretação na esfera artístico-cultural acontecem mais da direção de Português para Libras, visto que os surdos tomam ultimamente o papel de espectadores desses bens culturais. Novos desafios surgem quando os surdos assumirem o papel de artista, requerendo a interpretação de Libras para Português. Nesse sentido, Felício (2016) indica a necessidade de estratégias específicas para que o público ouvinte foque a atenção na expressão corporal do artista surdo.

A partir dessa problematização inicial sobre a atuação de TILSP em peças teatrais e de quando esses profissionais assumem a cena com caracterização, analisamos um projeto de participaçáo de TILSP na peça teatral "X-QUEM? - Origens", apresentada em Florianópolis-SC. O objetivo é descrever o fenômeno e compreender o processo de criação e os efeitos da caracterização do TILSP no teatro. Algumas questôes foram levantadas: como o intérprete de teatro medeia entre o texto de partida e o texto performático? Segundo, uma vez que o texto/discurso foi preparado, o que está envolvido em apresentá-lo no palco e, portanto, nas múltiplas semioses para a mediação ao vivo entre atores e público surdo?

A organização do presente artigo segue esse planejamento geral: após esta introduçấo, na seçấo 2, apresenta-se o quadro teórico em questão, conforme os Estudos da tradução e interpretação e os estudos linguísticos, baseados em Bakhtin e no Círculo e sua relaçáo com a esfera artísticocultural; na seçáo 3, apresenta-se o desenho metodológico desta pesquisa; na 4, analisa-se a caracterização e posicionamento de TILS em uma peça teatral, considerando-se essa esfera e o contexto de atuação; e, finalmente, na seção 5, fecha-se o texto e tecem-se reflexões finais sobre a as possibilidades de composição do TILS em peça teatral.

\section{Estudos da tradução e estudos linguísticos: articulaçóes necessárias}


Os Estudos científicos sobre o teatro traduzido para Libras ainda são em pequeno número. Faremos, assim, uma revisão dos estudos que tratam da tradução e interpretação de Libras de teatro no Brasil. O texto será desenvolvido a partir de Rigo (2014), Fomin (2018), Silva Neto (2017), como também de bibliografia estrangeira, a saber, de Pöchhacker (2004, 2015).

A relação simbiótica entre imagem, discurso e contexto enunciativo tem, por sua vez, suscitado numerosos estudos, pois, apesar de sua aparente naturalidade, não há consenso quanto à natureza e qualidade da influência mútua entre as múltiplas semioses para construçáo de sentidos pelos interlocutores. Pautados em pesquisas de Análise de Discurso, provinda de Bakhtin e o Círculo, consideramos que a construção enunciativa não pode desconsiderar os dados concretos da expressão social (BAKHTIN, 2016).

Sobre os diferentes contextos de interpretação, Pöchhacker (2004) propóe um modelo cujas dimensóes da interpretação se dáo por um amplo espectro, desde os fenômenos de interpretação, com um cenário que representa um contínuo dimensional que se estende de contextos internacionais a contextos intra-sociais. Entre estes dois polos está a interpretação de teatro para línguas de sinais. O autor (2015) também indica que no âmbito da interpretação de línguas de sinais pode-se classificá-la em oito contextos (educacional, jurídico, médico, saúde mental, reabilitação e serviço social, empresa/indústria e governo e religião, artes cênicas). Dessa forma,

\footnotetext{
[...] a interpretação de língua de sinais compreende uma variedade de configuraçōes distintas em comparação à interpretação de línguas faladas vocalmente, pois é necessária em praticamente todas as esferas da vida, desde a INTERPRETAÇÃO EDUCACIONAL até esportes e INTERPRETAÇÃO DE TEATRO (PÖCHHACKER, 2015, p. 370, grifo do autor).
}

Dentre os diversos contextos institucionais nos quais se espera que os intérpretes de línguas de sinais trabalhem, foram descritos desafios especiais para o teatro. Podemos citar a importância de preparar antecipadamente uma traduçáo eficaz do texto dramático, além de trabalhar com o diretor para entender completamente o texto teatral. Assim, a preparaçáo do intérprete deve ser semelhante à preparação e ensaio dos atores (FRISHBERG, 1990).

Por isso, assumimos, neste texto, o termo tradutor-intérprete de Librasportuguês, considerando que, apesar de a interpretação ser simultânea, ela é antecedida pelo estudo, tradução e criação, para ser apresentado em um 
espetáculo que trabalha com a improvisação e o inusitado. Assim, esse tipo de atuação envolve tanto características do trabalho de tradução como de interpretação.

Nos estudos da interpretação, uma imagem que se tem sobre o processo de interpretação envolve os conceitos de linguagem, cognição, interação e cultura, como ilustrado na figura 1, com base em Pöchhacker (2015). O campo da interpretação é composto por dimensóes que se completam, envolvendo linguagem (interpretação verbal), cultura (mediação de textodiscurso), cognição (cognição, informação, processo) e interação (mediação, discurso, construção de sentidos), muito próximos conceitualmente e que orientaram o processo de investigação teórica na interpretação. Há aspectos particulares em cada uma delas que colocam em diálogo essas diferentes dimensões do processo de interpretação.

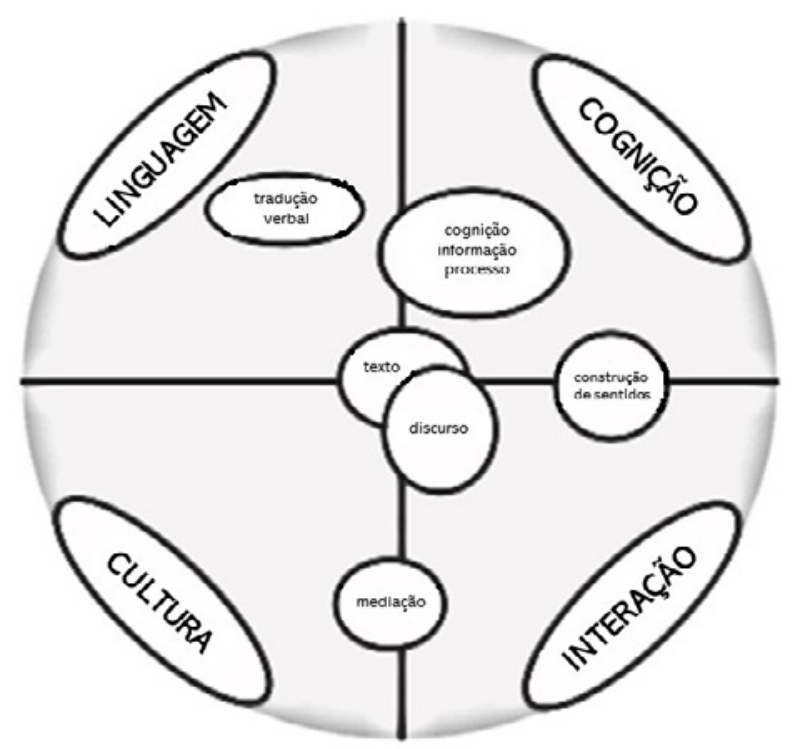

Fonte: Pöchhacker (2015, p. 64, tradução nossa)

Figura 1: Mapa de memes em estudos da interpretação

No âmbito da interação, estão envolvidos os aspectos de mediação, discurso e construção de sentidos. Nos polos da linguagem e interação estariam mais evidenciadas a linguagem não verbal, visto que na interação 
face a face a compreensão tem uma grande influência contextual e situacional, como também elementos de entonaçáo, velocidade de fala e expressōes faciais corporais, o que por muitos estudiosos é negligenciada, por considerarem apenas a linguagem verbal. Neste meme, a tradução do verbal é uma pequena parte do polo da linguagem, o que sugere o entendimento de que a linguagem é compreendida por outros elementos, além das palavras.

No Brasil, pela crescente visibilidade da Libras, como também pelas políticas linguísticas e educacionais que têm impulsionado o acesso aos bens culturais, vislumbramos um grande mercado de atuação para os TILSP. A Lei Brasileira de Inclusáo da Pessoa com Deficiência (Estatuto da Pessoa com Deficiência) (BRASIL, 2015), entre outras medidas, estabelece o direito à língua de sinais como mecanismo de acessibilidade, em diversas esferas, explicitando o "direito à cultura" e o acesso ao "teatro":

Capítulo IX sobre o Direito à cultura, ao esporte, ao turismo e ao lazer, diz: "Art. 42. A pessoa com deficiência tem direito à cultura, ao esporte, ao turismo e ao lazer em igualdade de oportunidades com as demais pessoas, sendo-lhe garantido o acesso:

I - a bens culturais em formato acessível;

II - a programas de televisão, cinema, teatro e outras atividades culturais e desportivas em formato acessível; e

III - a monumentos e locais de importância cultural e a espaços que ofereçam serviços ou eventos culturais e esportivos". (grifo nosso).

Nesse fragmento, percebemos o crescimento de peças teatrais acessíveis em Libras. É recorrente o anúncio de espetáculos com TILSP na cidade de Florianópolis, promovidos por diferentes companhias de teatro e em diferentes festivais. Por exemplo, no $24^{\circ}$ Festival Isnard Azevedo (setembro de 2019), dos 24 espetáculos teatrais, 11 contaram com equipe de intérpretes.

Fomin (2019) explica que esse crescimento está relacionado à Lei de Incentivo à Cultura (Lei Federal no 8.313 do dia 23 de dezembro de 1991), em que as companhias podem receber ao desenvolver uma peça acessível para pessoas com deficiência; para surdos está a colocaçáo de um tradutorintérprete. Geralmente, o contrato do TILSP é desenvolvido posteriormente a toda a peça planejada, do local, cenário e materiais estabelecidos. Esse fato prejudica a integração da Libras a dada peça.

Até recentemente, os campos de atuação de interpretação em conferência e audiovisual têm primado pela neutralidade e mínima 
interferência do tradutor, como também pela pouca mobilidade corporal e expressividade, as quais conferem um perfil e padrão de exposição e comportamento do tradutor-intérprete de línguas de sinais mais comedido e (in)visível. Visto que a vestimenta do tradutor-intérprete de Libras- Português, tradicionalmente, é composta por roupa preta para não atrapalhar a visualização das mãos. Essa premissa influenciou o início das atividades de intérpretes também na esfera artístico-cultural, como no teatro, consequência além disso da pouca articulação, planejamento e ensaio dos tradutores nas companhias teatrais.

$\mathrm{Na}$ figura 2, ilustramos a posiçáo lateral em que é colocado comumente o TILSP, utilizando de vestimenta preta. Apesar de estar relativamente próximo do ator e incorporando as expressôes e direção de corpo, ainda assim não é garantida a satisfação para espectadores surdos. A transposição do texto para a língua de sinais em teatro é chamada, por Richards (2016), de performance interpretada, indicando, ainda, a falta de produçáo do texto-discurso que sugira teatralidade, tendo em vista que há a falta de uma integração efetiva do tradutor-intérprete ao espetáculo. Assim, o tradutorintérprete deve transpor por meio de seu corpo a teatralidade.

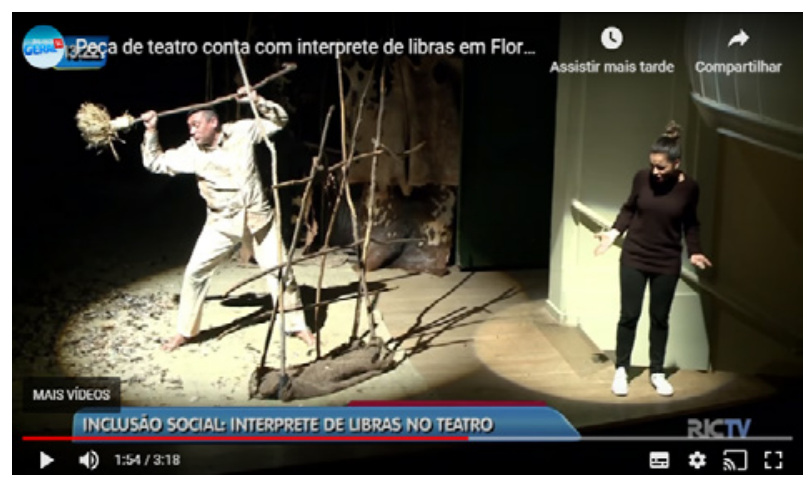

Figura 2: Peça de teatro com tradutor-intérprete de Libras Fonte: BALANÇO GERAL FLORIANÓPOLIS - 09/08/2019²

Ainda, sobre o posicionamento do tradutor-intérprete, na literatura, registra-se as diversas possibilidades de construçáo do posicionamento e da interação dos tradutores e intérpretes com os atores da peça. Esse espectro vai desde a posição lateral, passando pela interação total, confundindo-se

2Disponível em: <https://ndmais.com.br/videos/balanco-geral-florianopolis/peca-de-teatroconta-com-interprete-de-libras-em-florianopolis/>. Acesso em: 25 mai. 2020. 
o tradutor com um personagem, ao uso de interpretação sombra em que vários tradutores atuam simultaneamente, construindo uma performance sobreposta. A seguir, apresentamos um quadro com algumas possibilidades de posicionamento e sua breve descrição.

\begin{tabular}{|c|c|}
\hline POSICIONAMENTO & 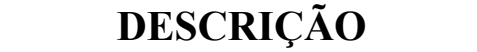 \\
\hline Intérprete-ator com movimento no palco & $\begin{array}{l}\text { Esse intérprete pode ter seu próprio papel e } \\
\text { mesmo interpretar todas as falas dos outros } \\
\text { atores, fazendo interaçóes na performance } \\
\text { com o elenco, ou seja, desloca-se no } \\
\text { palco para dar coerência cênica realizando } \\
\text { a interpretaçáo concomitantemente a } \\
\text { sua encenaçâo. Tal posicionamento faz } \\
\text { com que o profissional esteja no mesmo } \\
\text { enquadramento dos demais atores. }\end{array}$ \\
\hline $\begin{array}{l}\text { Intérprete e contra regra com } \\
\text { movimento no palco }\end{array}$ & $\begin{array}{l}\text { Esse intérprete desenvolve a interpretação } \\
\text { e contribui com a estruturação cênica } \\
\text { e mudança de cenário ou de objetos } \\
\text { no palco, coordenando o momento de } \\
\text { interpretação e de contra regra. }\end{array}$ \\
\hline $\begin{array}{l}\text { Interpretação sombra com vários intérpretes } \\
\text { (shadow interpretation) }\end{array}$ & $\begin{array}{c}\text { Nessa estrutura, os intérpretes "sombreiam" } \\
\text { os atores, seguindo-os, no palco, durante } \\
\text { a interpretação. Como os intérpretes estão } \\
\text { ao lado dos atores, o público surdo pode } \\
\text { prestar atenção na língua de sinais e nos } \\
\text { atores da peça ao mesmo tempo. Esses } \\
\text { intérpretes podem ter seus próprios papéis } \\
\text { ou atuar como extensóes dos outros atores, } \\
\text { de modo que frequentemente se misturam } \\
\text { com a peça. }\end{array}$ \\
\hline $\begin{array}{l}\text { Intérprete no palco - lateral do } \\
\text { palco com interaçấo }\end{array}$ & $\begin{array}{l}\text { Consiste na interpretação de todas as falas e } \\
\text { fatos da peça. Pode haver a interação com o } \\
\text { elenco, desde os atores, usando libras junto } \\
\text { com os intérpretes, em alguns momentos, } \\
\text { ou o elenco interagindo com o intérprete. } \\
\text { A presença no plano de visão do espaço } \\
\text { cênico é dificultada pela posiçáo lateral. }\end{array}$ \\
\hline $\begin{array}{l}\text { Intérprete no palco - lateral do } \\
\quad \text { palco sem interaçáo }\end{array}$ & $\begin{array}{l}\text { Este posicionamento vai desde o canto } \\
\text { do palco até um espaço mediano, a frente } \\
\text { dos atores. Um único tradutor-intérprete, } \\
\text { por vez, expóe todo o espetáculo. Pode- } \\
\text { se trabalhar em equipe com apoio e } \\
\text { revezamento. Uma desvantagem é que o } \\
\text { membro da plateia surdo precisa escolher } \\
\text { entre assistir à açáo no palco ou o intérprete } \\
\text { profissional do lado. }\end{array}$ \\
\hline
\end{tabular}




\begin{tabular}{|c|c|}
\hline POSICIONAMENTO & DESCRIÇÃ̃O \\
\hline Intérprete fora do palco - abaixo do palco & $\begin{array}{l}\text { Coloca-se o intérprete no nível da plateia } \\
\text { para que ele interprete apenas para } \\
\text { poucos surdos, que estiverem presentes na } \\
\text { apresentaçáo. Possui a mesma desvantagem } \\
\text { do posicionamento anterior: o público } \\
\text { precisa realizar um certo esforço para } \\
\text { enquadrar o profissional e o palco no } \\
\text { mesmo campo de visão. }\end{array}$ \\
\hline
\end{tabular}

Quadro 1: Tipos de posicionamento de Tradutores-intérpretes de línguas de sinais

Fonte: Produzido pelos autores

Este quadro apresenta algumas possibilidades de posicionamento dos tradutores-intérpretes e em cada uma delas há outras possibilidades de gradação do nível de interação e integração, da associação com o figurino e a maquiagem dos tradutores-intérpretes. Em todas as formas, o TILSP é um elemento de interferência estética.

Mencionamos que, comumente, o tradutor-intérprete veste-se com uma roupa preta, como apresentado na figura 2. Para Silva-Neto (2017, p. 50), “o figurino se reconfigura como uma 'segunda pele do ator' com o progresso da estética realista. Pensando em sua função, vestir é o primeiro papel desse elemento". Por sua vez, Lucena (2017, p. 82) descreve que o processo de criar um figurino revela a transgressáo de náo apenas versar de uma língua para outra, mas se constrói um personagem. Nessa composição complexa, coloca o tradutor-intérprete em um "lugar inventivo e expandido, bem além de 500 caracteres". A autora faz alusão a normas de produção escrita que tolhem a expressividade dos autores ao limitar o número de caracteres, assim como ao impor um padrão de caracterização dos tradutores-intérpretes se inibe o poder criativo e sensível da composição do figurino do tradutor-intérprete ao compor uma obra de esfera artísticocultural.

Fomin (2018b, p. 154) também estudou a tradução em peças de teatro e descreveu dentre outros aspectos "o cenário, figurino e iluminação do espetáculo; questôes relacionadas à atuação dos atores e interação com a plateia e elementos do cenário; quantidade, localizaçáo e esquema de trabalho dos TILS; estratégias de interpretação utilizadas pelos TILS", principalmente, as relacionadas ao apontamento para os elementos do espaço de sinalização. A autora considera que estes aspectos fazem parte da verbo-visualidade em cena. Considera, também, que "é importante que o figurino, maquiagem e iluminação sejam pensados anteriormente para 
compor a proposta estética do espetáculo" (FOMIN, 2018a, p. 85)

A maquiagem, por sua vez, é importante para a composição do espetáculo, pois contribui com a criação do personagem e a transformação estética dos atores. Geralmente, os tradutores-intérpretes de Libras-Português apresentam-se com uma maquiagem leve ou sem nada a destacarem na sua face. Esse padrão foi construído histórica e socialmente pelas orientaçôes de neutralidade que fora imposto aos mediadores de comunicação:

Dentro das Artes Cênicas, a maquiagem é e tem se tornado um dos principais elementos da encenaçấo, pode-se confirmar isso tanto pelo crescimento de profissionais da área quanto pela valorização desse trabalho (seja por meio de visibilidade midiática seja por meio de incentivação monetária). Ela afirma os personagens como pessoas reais, caracteriza e descaracteriza indivíduos, possibilita a criaçáo de outros seres, e valoriza a interpretaçáo dos atores (SILVEIRA, 2016, p. 26).

Para Rigo (2013, p. 54-55), "as luzes direcionadas ao tradutor intérprete sáo fortes, o que permite o uso de maquiagem que reforce as marcas gramaticais faciais tornando-as bastante visíveis e expressivas para o espectador." A autora ainda distingue dois tipos de maquiagem, uma que apenas minimiza o brilho da pele e outra chamada de maquiagem teatral, que envolve uma pintura do rosto mais elaborada e carregada, remetendo a um personagem, por exemplo. Podemos afirmar que maquiagens especiais usadas por TILSP em peças teatrais é recente.

Apontamos que essas pesquisas no campo dos estudos da tradução e interpretação de línguas de sinais e a problematização sobre o figurino, luz e posição do TILSP de uma peça teatral convergem para a compreensão de que a linguagem não se restringe à expressão linguística, mas transborda em múltiplas semioses, entre elas, a caracterização do tradutor-intérprete e sua integração no espetáculo, concordando com os estudos dialógicos da linguagem.

Bakhtin/Voloshinov (1997) também trata da relação entre atividade mental e enunciação, incluindo visual:

Quando a atividade mental se realiza sob a forma de uma enunciação, a orientaçáo social à qual ela se submete adquire maior complexidade graças à exigência de adaptação ao contexto social imediato do ato de fala, e, acima de tudo, aos interlocutores concretos. Tudo isso lança uma nova luz sobre o problema da consciência e da ideologia. Fora de sua objetivação, de sua realização num material determinado (o gesto, a palavra, o grito), 
a consciência é uma ficção. [...] enquanto expressão material estruturada (através da palavra, do signo, do desenho, da pintura, do som musical, etc.), a consciência constitui um fato objetivo e uma força social imensa (BAKHTIN/VOLOSHINOV, 1997, p.117-118; grifo do autor).

Nesse sentido, essas diferentes modalidades de significação integram uma unidade comunicativa, sendo interrelacionadas e dissociadas apenas didaticamente, visto que no conjunto de um espetáculo a construção de sentidos é percebida, sentida e vivida e pela imersão na cena dialógica.

Fundamentados na análise dialógica do discurso, concebemos que a linguagem não está centrada no aspecto verbal e que, por sua natureza dialética e sincrética, compactuamos com a ampliação das reflexôes até entâo desenvolvidas sobre a tradução e aplicação dos conceitos e análises de línguas em uso (BRAIT, 2012).

Bakhtin (2004) afirma que os elementos concretos (as imagens e o vocal - o ritmo e a entonação) só podem ser subtraidos do discurso e do seu conjunto artístico de forma abstrata e artificial, uma vez que se interpenetram e se condicionam mutuamente. Assim, apreendemos uma análise, fundamentados no conceito de multimodalidade. Construímos um quadro para indicar alguns recursos que co-ocorrem em um espetáculo (quadro 2).

\begin{tabular}{|c|c|}
\hline MULTIMODALIDADE & RECURSOS SEMIÓTICOS \\
\hline Linguístico & $\begin{array}{c}\text { Falas em língua vocal-auditiva (entonação, } \\
\text { ritmo, tom volume, como também } \\
\text { o silêncio), Língua de sinais (ritmo e } \\
\text { entonaçấ, velocidade, Escrita (tipo } \\
\text { de fonte, tamanho, negrito, itálico, } \\
\text { espalhamento, cores, disposiçâo). }\end{array}$ \\
\hline Auditivo e sinestésico & $\begin{array}{c}\text { Som (música, efeitos sonoros, fala, vídeos, } \\
\text { como também a vibraçá do som para as } \\
\text { pessoas surdas. }\end{array}$ \\
\hline Visual & $\begin{array}{c}\text { Imagens estáticas e em movimento no } \\
\text { auditório, no palco ou fora dele (fotografia, } \\
\text { desenhos, animaçôs, ícones). } \\
\text { Luminosidade, cores, tamanho desses } \\
\text { recursos, com também a ausência de luz } \\
\text { total. } \\
\text { Objetos, adereços que compóem as cenas, } \\
\text { maquiagem e figurino. } \\
\text { Intensidade dos sinais, expressóes faciais. }\end{array}$ \\
\hline
\end{tabular}




\begin{tabular}{|c|c|}
\hline MULTIMODALIDADE & RECURSOS SEMIÓTICOS \\
\hline Gestual & $\begin{array}{c}\text { Ações, descriçóes, movimento e direção do } \\
\text { corpo, expressóes faciais. }\end{array}$ \\
\hline Espacial & $\begin{array}{c}\text { Movimentaçáo e posicionamento dos } \\
\text { atores. Posicionamento do corpo do } \\
\text { tradutor-intérprete no palco e dos } \\
\text { personagens, como também dos objetos/ } \\
\text { adereços da peça em cenas. }\end{array}$ \\
\hline
\end{tabular}

Quadro 2: Multimodalidade em peça teatral

Fonte: Produzido pelos autores

Seja qual for o suporte ao qual a linguagem se ampare, afirmamos que a tradução e interpretação de/e para a Libras, na esfera teatral, ocorre simultaneamente a muitos desses recursos semióticos, de maneira que o espectador surdo construirá sentidos a partir do conjunto discursivo e não apenas com base nos sinais da Libras. A seguir, apresentamos a metodologia da pesquisa e a peça selecionada para este estudo.

\section{Metodologia de pesquisa}

Aspectos (filosóficos) e os procedimentais (práticos) da metodologia serão brevemente discutidos a seguir. Concebemos que viver o objeto de estudo construído contribui para a elaboração do problema de pesquisa e influencia os modos de analisar o fenômeno. Nesse sentido, indicamos que os autores deste texto trabalham como formadores de tradutores e intérpretes de Libras-Português e têm diferentes experiências com tradução e interpretação de discursos na esfera artístico-cultural.

Este se configura como um estudo de caso oriundo de pesquisa proveniente do Núcleo de pesquisas em Interpretação e Tradução de Línguas de Sinais - Intertrads da UFSC. As reflexóes teóricas desse projeto são amparadas na prática tradutória-interpretativa teatral. $\mathrm{O}$ projeto objetiva contribuir para o estudo dramatúrgico com Libras e a concepção de Libras como direito linguístico de acesso aos bens culturais. O que o motiva é a relativa ausência e pesquisas contemporâneas no Brasil que versem sobre a esfera artístico-cultural, como as de Rigo (2013), Fomin (2018), Silva-Neto (2017), assim como o desejo de promover a construçáo de conhecimento no campo dos Estudos da Tradução e Interpretação de línguas de sinais ETILS. 
Esta pesquisa segue uma abordagem qualitativa e se configura como do tipo descritiva usando de "estudo de caso". A descrição visa à compreensão completa do fenômeno. Nessa perspectiva, os pesquisadores têm pouco controle sobre os eventos e o foco se encontra em fenômenos contemporâneos inseridos em contexto da vida real (YIN, 2010), como o de espetáculo teatral.

\section{Participante, procedimentos, instrumentos}

Como procedimento de construção dos dados, compreendemos que nesse tipo de pesquisa o fenômeno é observado em seu ambiente natural. Os dados foram coletados por diversos meios, tais como: documentos (roteiro da peça teatral, fotos); observação participante; artefatos físicos (figurino).

Nesta pesquisa, em particular, abordaremos a tradução e produção de "X-QUEM? - Origens" (2019), apresentado no Pedro Ivo em Florianópolis - SC, como parte dos projetos da Mutantes Cia de Teatro e congregou a tradução para a Libras, realizada pelo tradutor Wharlley dos Santos, em 2019, segundo autor desse artigo.

Neste artigo, por limite de espaço, focaremos na descrição dos aspectos de caracterização e não abordaremos, por exemplo, aspectos de preparação (estudo do roteiro).

\section{Um caso de caracterizaçáo: análise do projeto}

Nesta seção do artigo, apresentamos o caso analisado da interpretaçãoatuação na peça e "X-QUEM? - Origens" (2019). Diante da singularidade do trabalho do tradutor-intérprete, nessa peça, assumimos o termo "interpretação-atuação".

\section{a) Primeiros passos}

No ano de 2016, a RPR Produçôes, empresa de teatro sediada no Rio de Janeiro (RJ) e com filial em Florianópolis (SC), iniciou um processo de incentivo de plateia, com objetivo de popularizar as produçóes artísticas/ culturais, em formato de teatros musicais, também para surdos. Ainda no ano de 2016, recebemos um contato para ofertar acessibilidade em 
produções, tendo em vista que o público surdo, existente na cidade, não era contemplado em nenhuma das produçóes.

Sendo assim, fomos convidados a desenvolver a funçáo de tradutorintérprete de Libras-Português (TILSP), enquanto um recurso de acessibilidade. Concebíamos que uma maior interação do público seria possível se o TILSP saísse desta posição de fora do espetáculo e se integrasse com o elenco da peça, por meio do uso de figurino e maquiagem específicos, como também de sua movimentação no palco. Todavia, esta pesquisa não compreende a opiniáo do público que frequentou sobre essa forma de se interpretar-atuar o teatro, nicho para futuras pesquisas.

Percebemos uma integração do intérprete antes inimaginável com a peça, sendo inclusive vista com apreço pela direção do espetáculo que observou melhor fluidez no palco. No ano seguinte, o processo foi aperfeiçoado e agora já se pensava, no começo do planejamento da peça, o figurino e a maquiagem do profissional TILSP, de forma que se integrasse por completo e não ficasse na posiçấo que outrora o mesmo era colocado, de canto, com roupa preta e um foco de luz único, o que ocorreu até o ano de 2019, quando encerramos a nossa participação nesta companhia.

Pouco tempo depois, fomos convidados para a Mutante Cia de Teatro, que buscava desenvolver um projeto semelhante, porém, desta vez, a companhia era formada por diversos alunos da graduação e da pós-graduação da Universidade Estadual de Santa Catarina (UDESC). O objetivo era desenvolver uma peça que parodiava o universo já conhecido dos X-MEN ${ }^{\circledR}$ - uma equipe épica de super-heróis de histórias em quadrinhos, publicadas nos Estados Unidos, pela Marvel Comics, autoria de Stan Lee e Jack Kirby. Por sua vez, a peça "X-QUEM? - Origens" teria super-heróis brasileiros vivenciando os dilemas da descoberta dos poderes e de como lidar com os vilóes e seus planos mirabolantes.

Fomos convidados para participar da discussão da construçáo de um personagem que tivesse um papel na trama. A diretora da peça, Audrei Hüllen $^{3}$, nos propôs trabalharmos com um personagem da série original. Contudo, ainda não tínhamos ideia de quais dos personagens canônicos poderia ser interpretado pelo TILSP, enquanto interpretava toda a peça. Todo o processo foi colaborativo, por meio de reunióes, em que se tinha

\footnotetext{
${ }^{3}$ Audrei Hüllen é graduada nos cursos de Comunicação Social com Habilitação em Publicidade e Propaganda e em Licenciatura em Teatro. Atualmente, trabalha como atriz, diretora e social media em sua própria companhia, Mutante Cia de Teatro. Além disso, é profissional da voz, trabalha com locução e voz original. E-mail: audhull@gmail.com.
} 
como objetivo delimitar os personagens, suas caracterizaçóes e a construção do personagem que seria o intérprete em si.

A peça recebeu o nome de "X-QUEM? - Origens", ambientada nos anos 80 , que conta a história de um jovem rapaz que vai para escola de heróis aprender com o maior ídolo de todos os tempos, o Interruptor, que no transcorrer da peça demonstra aos seus alunos os perigos desta função.

A peça foi apresentada no Teatro Pedro Ivo, nos dias 21 e 27 de agosto de 2019, tendo a entrada franca, graças à Lei de Incentivo à Cultura, além da acessibilidade em Libras, contando também com a Audiodescrição realizada pela Tagarela Produçôes. A seguir, apresentamos a análise do processo e configuração.

\section{b) Construção do personagem para o Tradutor-intérprete}

A direção da peça propôs alguns caminhos para a construção do personagem do TILSP, o escolhido foi o Professor Charles Xavier que, na peça, seria o Professor X (Figura 2). O dilema inicial foi a sua forma de apresentação, tendo duas opçóes: uma em que ele anda normalmente, remetendo ao início da história na qual descobre seus poderes; e outra opção seria apresentá-lo como cadeirante, resultado de um tiro que atingiu sua coluna, fazendo com que ele sofresse com uma escolha, continuar andando com ajuda de uma droga desenvolvida por um dos seus alunos, ou manter seus poderes e nunca mais andar.

Para o ensaio aberto, optamos em utilizar a primeira versáo do personagem, ou seja, ele em pé na primeira fase (Figura 03). Tal ensaio aconteceu no teatro do SESC e contou com a presença de 01 aluno surdo da Universidade Federal de Santa Catarina (UFSC), da licenciatura em Letras-Libras, e 01 aluna ouvinte do bacharelado do mesmo curso, que por nosso convite participaram deste ensaio para nos dar um retorno quanto: (i) posição do TILSP no palco, (ii) interação do intérprete-personagem com os demais, (iii) figurino e maquiagem e (iv) nuances da luz versus a sinalizaçáo. 


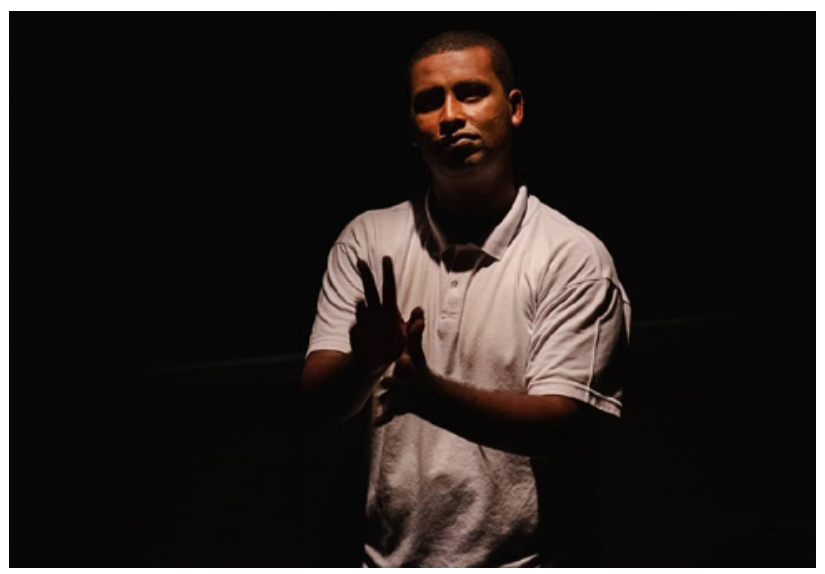

Figura 3: Tradutor-intérprete sem caracterização no ensaio aberto

Fonte: Arquivo pessoal,

Fotografia de Mhirley Lopes (crédito)

No ensaio aberto, por questáo de tempo, não tivemos acesso ao figurino e maquiagem dos personagens, já que ainda não estavam prontos para serem utilizados Optamos por utilizar a camisa branca e calça preta, logo os itens (iii) figurino e maquiagem e (iv) nuances da luz versus a sinalização não foram analisados. Apenas a posição no palco foi criticada na avaliação piloto dos espectadores convidados, pois o teatro em que estávamos não oferecia mobilidade para nos deslocarmos e, também, não havíamos projetado uma interação entre o personagem e os demais.

Depois desse ensaio aberto, realizamos uma reunião com o público para coletar suas impressóes sobre toda a peça. Essa apresentação teve duração média $1 \mathrm{~h} 15 \mathrm{~m}$, compreendendo apenas o primeiro ato, já ensaiado. Em suma, segundo o público presente, a posição do personagem atrapalhou a percepção do público dos aspectos não-verbais, tais como as movimentações e interaçóes dos personagens no palco. Isso aconteceu em função da falta de estrutura que o palco nos oferecia para apresentação. O que nos chamou atenção é que não apenas o surdo presente, mas também o público ouvinte, que não conhecia absolutamente nada da língua, ficou incomodado com a presença de um personagem, no canto do palco, com uma luz solitária, realizando uma série de movimentos com suas mãos. Após esse ensaio aberto e com as impressóes de um público surdo, a produçáo em conjunto com o tradutor-intérprete discutiu sobre o figurino do TILSP e sua inserção na 
movimentação dos personagens da peça.

\section{c) Figurino e Maquiagem do personagem para o Tradutor-intérprete}

O passo posterior no projeto foi a construção do figurino e maquiagem do personagem para o tradutor-intérprete. Nossas primeiras discussóes foram digerir os comentários elaborados pelo público que assistiu à peça. Neste momento, começamos a procurar referências do personagem em imagens na internet, ao mesmo tempo em que definimos que passaríamos a adotar o personagem e sua segunda fase, conforme a Figura 3, pois o seu equipamento, nomeado de Cérebro, também seria utilizado na peça e tal aparato só aparece a partir da segunda fase do personagem. Então, começamos a procurar os materiais necessários.

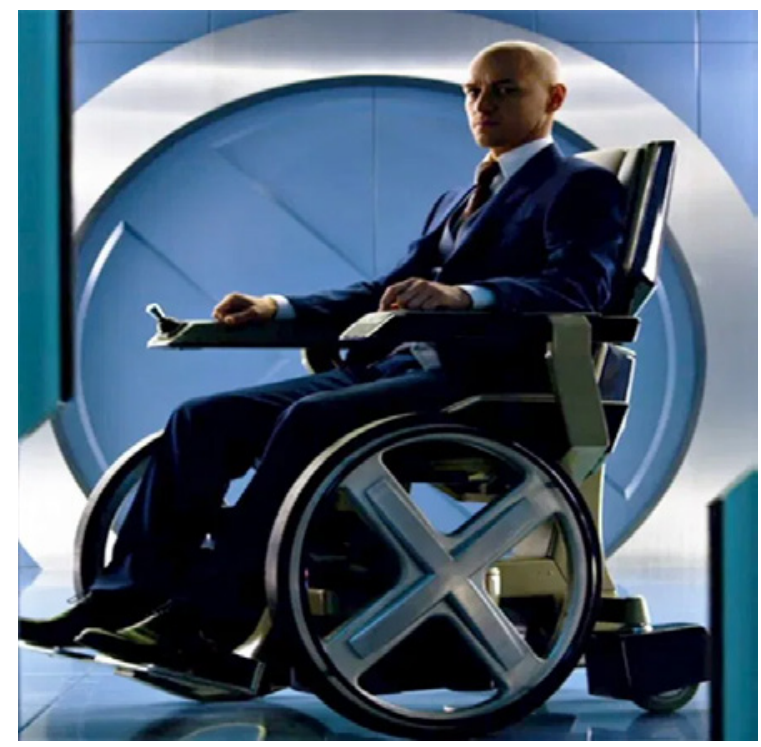

Figura 4: Personagem Charles Xavier no universo dos X-Men

Fonte: Site Pipoca Moderna (2019)

O Professor X é reconhecido pelos criadores da franquia como o mutante mais poderoso que já pisou na terra, seus poderes são derivados 
da telepatia, sendo capaz de ler a mente de outros e projetar seus próprios pensamentos, numa distância de até 400 quilômetros. Para aumentar este alcance, ele usa a Cérebro, uma máquina capaz de descobrir a localização de qualquer mutante no mundo. Em todos os filmes relacionados à franquia, o professor utiliza um terno de cor serena para indicar a sobriedade da profissão de professor.

Decidimos manter a sobriedade do personagem, retirando apenas a gravata, pois ela poderia incomodar, ao apertar o pescoço, demandando um tempo e as mãos para afrouxá-la. Uma outra questão é que a gravata poderia ficar movimentando enquanto realizávamos a interpretaçáo-açáo, tornandose um distrator para o público surdo.

O passo seguinte foi a preparação para o uso da cadeira de rodas com a participação em oficina de locomoção em cadeira de rodas, pois o personagem iria se movimentar no palco. Sendo assim, necessitávamos de afinidade com este objeto cênico para que a performance fosse a mais fluida possível. Após a semana de formaçáo, tivemos três oportunidades de ensaiar utilizando o objeto. No ensaio inicial, observamos que os braços da cadeira estavam prejudicando a movimentação dos braços para realizar os sinais. Dessa forma, os braços da cadeira de rodas foram removidos e em nada mais atrapalhou a sinalizaçáo. O terno característico foi escolhido com um tom claro para contrastar com a cor de pele do profissional, já que a apresentação aconteceria num palco com iluminação específica.

Ainda, foi desenvolvido, pela diretora de arte da peça, Joana Kretzer Brandenburg 5 , o Cérebro, que na história original é uma máquina de localização de mutantes, mas que foi elaborada como um capacete com luzes de LED em azul (Figura 5), que conferiu iluminação individual para o TILSP em momentos de blackout; uma segunda função é a cênica, já que é utilizada também pelos outros personagens em uma das cenas da peça, em que eles recebem os seus nomes de heróis. Sua terceira função é de reforçar e remeter à obra original dos $\mathrm{X}-\mathrm{MEM}^{\oplus}$, utilizada como uma referência.

O próximo passo foi a discussão da maquiagem, assinada pela

5Joana Kretzer Brandenburg é Doutoranda em Teatro pela Universidade do Estado de Santa Catarina (UDESC), membra do grupo de pesquisa Imagens Políticas. Possui graduação em Design de Produto pelo Instituto Federal de Educação, Ciência e Tecnologia de Santa Catarina (2012), graduaçáo em Licenciatura e Bacharelado em Teatro (2014) e Mestrado em Teatro (2017) pela Universidade do Estado de Santa Catarina. Tem experiência na área de Artes, com ênfase em Figurino e Cenografia. Atualmente, estuda direçấo de arte como linguagem, com foco em obras artísticas do universo pop-nerd. 
maquiadora Laura Pasternack ${ }^{6}$. O estilo idealizado para a peça foi o PopArt, que consiste em linhas pretas fortes no contorno do rosto para deixá-lo mais quadrado, com a boca também marcada em preto, para dar um ar mais cartunesco aos personagens, já que a história se passa nos anos 80 e a movimentaçáo no palco é dada por meio de estruturas que simulam os quadrinhos das HQ's. Ainda, foram usadas muitas cores relacionadas a esta década, sendo estas cores vibrantes e fluorescentes. A inspiração vem de Roy Lichtenstein $^{7}$ (1923-1997), que aplicou tal estilo de desenho em suas obras, como histórias em quadrinhos e anúncios publicitários. Abaixo, nas figuras 4 e 5 , podemos observar a composição final do personagem.

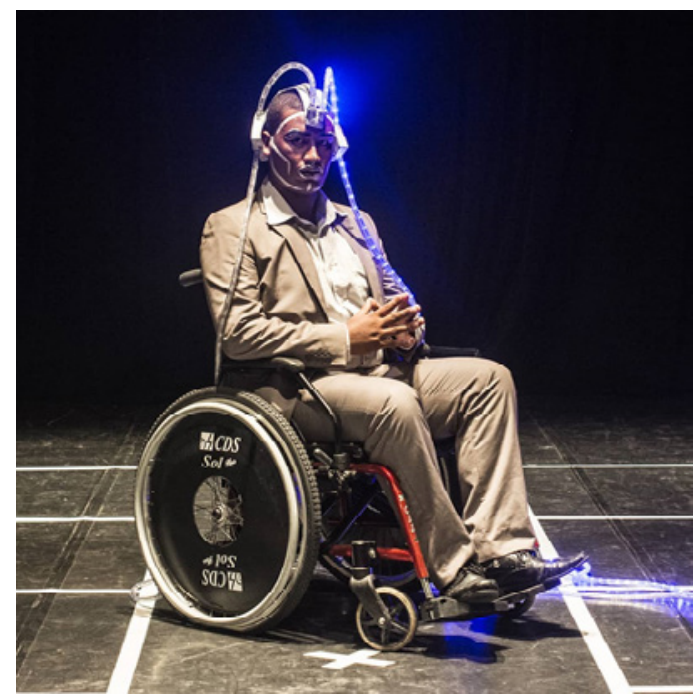

Figura 5: Figurino e maquiagem do personagem para o tradutor-intérprete

Fonte: Acervo pessoal dos autores

Fotografia de Rodrigo Sambaqui (crédito)

${ }^{6}$ Lara Pasternak é formada em licenciatura em Teatro pela Universidade do Estado de Santa Catarina, também é maquiadora artística e visagista. Hoje trabalha em sua produtora de arte, a Start Artístico, além de ter seu próprio curso para formação de novas maquiadoras artísticas. E-mail: larapascomunicacao@gmail.com.

${ }^{7}$ Roy Fox Lichtenstein (Nova Iorque, 27 de outubro de 1923 - Nova Iorque, 29 de setembro de 1997) foi um pintor estado-unidense identificado com a Pop Art. Na sua obra, procurou valorizar os clichês das histórias em quadrinhos como forma de arte, colocando-se dentro de um movimento que tentou criticar a cultura de massa. (LICHTENSTEIN, 2020). 


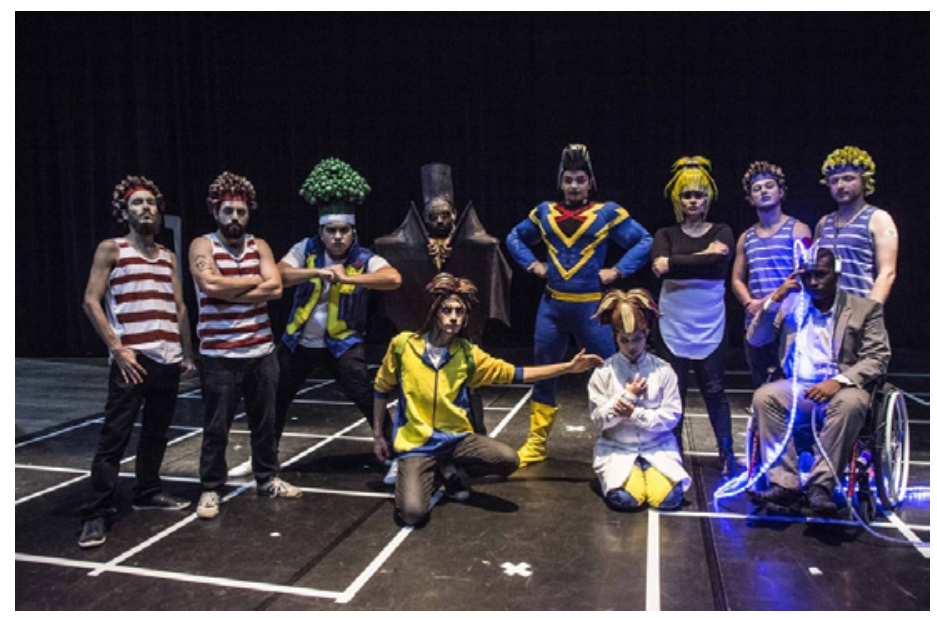

Figura 6: Figurino do intérprete em comparação ao dos personagens

Fonte: Informe Floripa (2019) ${ }^{8}$

Fotografia de Rodrigo Sambaqui (crédito)

Os recursos multimodais utilizados pelo tradutor-intérprete, como descrito anteriormente, são: figurino, maquiagem e adereços, de acordo com o contexto específico da estória contada e o recurso tecnológico como a iluminação. Podemos afirmar que o tradutor-intérprete, nesta peça, compóe a obra artística.

Entendemos o gênero espetáculo teatral, enquanto objeto artístico, como um projeto discursivo verbo-visual, composto pelo que é proferido pelos atores verbalmente, mas também e de igual importância, pela representação que se dá em cena, pelos objetos e elementos cênicos, pela iluminaçáo, figurino, maquiagem dos atores etc. Ou seja, os enunciados produzidos são determinados também pelas coerçôes de uma determinada esfera ideológica (a esfera artística), e de um determinado gênero discursivo (espetáculo teatral) (FOMIN, 2018a, p. 104).

Como descrito, na peça estudada, a apresentaçáo do tradutorintérprete transgride as normas convencionadas, mas se firma coerente com o gênero artístico que transpassa qualquer padrão para impactar o espectador, neste caso, tanto o público surdo como o público ouvinte,

${ }^{8}$ Disponível em: <http://www.informefloripa.com/2019/08/26/x-quem-origens-faz-no-dia27-a-segunda-apresentacao-gratuita-em-florianopolis/>. Acesso em: 24 jun. 2020. 
devido a integração da língua de sinais no espetáculo, principalmente, do corpo do tradutor-intérprete.

Tudo é traduzível precisamente porque traduzir é criar na língua de chegada sentidos "co-respondentes" a sentidos da língua de partida, e não buscar equivalências entre palavras, que a rigor sequer existem, uma vez que cada palavra é valorada, vem de um recorte da realidade, social e histórico, e dado que as sociedades e línguas diferem entre si (SOBRAL, 2018, p. 13).

Nessa perspectiva, a tradução não se restringiu ao roteiro, ao texto escrito, mas ao espírito da obra, ao projeto discursivo como um todo envolvendo múltiplas semioses verbais e não verbais, contando com figurino e maquiagem específico.

\section{d) Posiçáo no palco}

Muito discutimos sobre a posição do tradutor-intérprete no palco. Convencionalmente, o espaço ocupado por este profissional, nos contextos artísticos, é o canto esquerdo, com uma iluminação única, em apenas um tom geralmente quente, para dar contraste ao vestuário. Todavia, já havíamos definido que não seria desta forma neste espetáculo.

Durante os ensaios, começamos a desenhar as movimentaçôes do personagem em cena. Em diversas delas, essa movimentação era necessária, para integrá-lo ainda mais à peça e estabelecer uma relação de coerência para a narrativa. O que sabíamos era que, em suma, ele era o primeiro a entrar no palco, para dar início aos avisos narrativos de segurança do próprio teatro e o último a sair, por conta da passagem da cadeira de rodas.

Ao voltarmos para o roteiro do espetáculo, identificamos os momentos em que essa movimentaçáo seria imprescindível para dar ritmo à narrativa. Podemos citar, por exemplo, a primeira música do espetáculo, que mostrava o personagem principal - Tony - chegando em sua escola de heróis, onde encontrava o professor e cantava "Ual, finalmente cheguei, olha esse lugar! Tão cheio de heróis. Caraca, olha aquele careca só não posso falar, senão dá copyright" (HÜLLER, 2019. p. 02). Imediatamente, no ensaio, propusemos que essa interação acontecesse entre a intérprete (como professor X) e o personagem, fazendo com que a peça fosse mais fluída. A cena final foi construída para que no momento em que Tony começasse a cantar, o intérprete se aproximasse do canto direito do palco, e Tony o apresentasse ao público 
como Professor X e intérprete da peça. Neste momento, o Professor X fazia sua movimentaçáo corporal característica, levando os dedos indicador e médio até a cabeça (Figura 9), apresentando seu poder telepático.

Em todas essas movimentaçóes, os personagens envolvidos se encontravam em uma posiçáo no palco e realizavam a interaçáo dita pelo roteiro e, por isso, a oficina de mobilidade com a cadeira de rodas se mostrou promissora anteriormente. No transcorrer dos ensaios, observamos que essas interaçôes precisavam ser pontuais e não seria possível ficar se movimentando a todo momento, pois a interpretaçáo exige esforço cognitivo e a atuação cênica demandava esforço físico para movimentar a cadeira de rodas. A peça possui no total $2 \mathrm{~h}$ e $30 \mathrm{~min}$., dividida em atos. Assim, se fosse ficar se movimentando com a cadeira, seguindo os personagens, náo seria possível interpretar a peça inteira, dado o cansaço físico.

Ao chegarmos ao teatro para os dois ensaios finais, optamos por nos colocar à direita do palco, na perspectiva do público, porém com um foco de luz maior, permitindo pequenos deslocamentos, para ser possível chegar até a metade do palco e estabelecer essas interaçóes com os demais personagens, como apresentado na Figura 7.

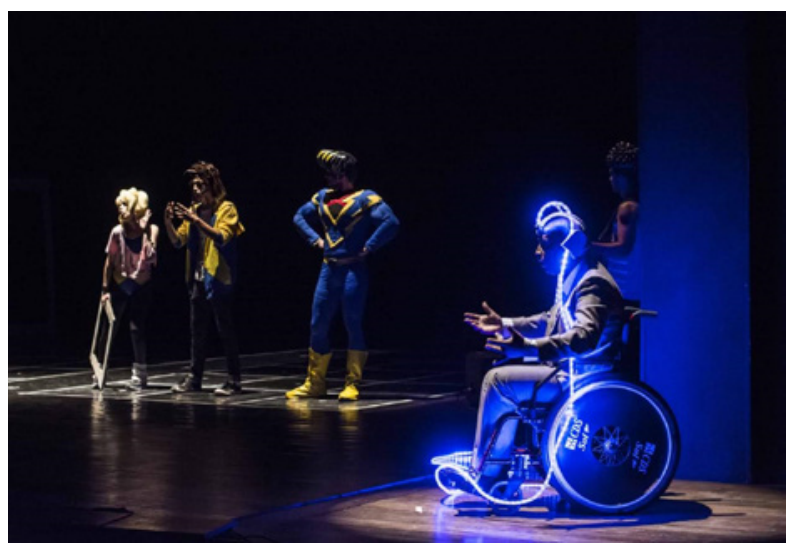

Figura 7: Posição no palco do tradutor-intérprete

Fonte: Acervo pessoal dos autores

Fotografia de Rodrigo Sambaqui (crédito)

Por mais que o roteiro do espetáculo, composto de dois atos, com pouco mais de 60 minutos cada, tivesse todo decorado pelo tradutor- 
intérprete, que já havia trabalhado nessa peça há mais de 8 meses, imprevistos acontecem e muitas das vezes os atores improvisam as falas. Nessas situaçóes, buscando não pegar o tradutor-intérprete desprevenido, optamos por ignorar as improvisaçôes e persistir na tradução do texto que fora decorado anteriormente, pois, dessa forma, o esforço cognitivo de entender o que estava se passando e de como o texto havia sido mudado foram dirimidos.

Descrevemos que, nessa peça, a opção foi pela mobilidade do tradutorintérprete no palco, ao mesmo tempo que ele era um cadeirante. Apesar de ter um espaço específico com foco de luz reservado para ele ao lado do palco, no projeto ele poderia percorrer o palco e interagir com os atores.

Às vezes, detalhes importantes da trama são comunicados pelas açốes dos personagens no palco. Por exemplo, uma carta importante é jogada na lareira para nunca mais ser entregue ao destinatário pretendido. Rocks (2011) discutiu a complexidade dos pontos concorrentes de foco para o público surdo que frequentemente precisam negociar entre olhar para a interpretação do diálogo feita pelo intérprete de língua de sinais e narrativa visual produzida pela performance dos atores. Isso se deve ao fato de os intérpretes serem frequentemente colocado ao lado do palco. Quando a ação do palco (apenas informações visuais) ocorre, intérpretes direcionam a atenção do público surdo para o palco "dando foco". Na verdade, eles guiam os olhos dos surdos para a açáo que eles podem perder enquanto estão com o foco nos intérpretes. Direcionando o foco ou "jogando o foco" é feito de algumas maneiras: os intérpretes podem cruzar os braços e olhar para o palco, olhar para o palco ou mudar rapidamente de olhar na direção da ação. A evidência de tais estratégias de "direcionamento do foco" foi vista de várias maneiras e frequentemente ao longo deste estudo (GANZ HORWITZ, 2014, p. 04).

Desse modo, nem todos os diálogos devem ser interpretados simultaneamente, por vezes, o tradutor-intérprete precisa coordenar o tempo em que o público deve estar atento à cena e o tempo em que ele pode retomar a situação, ocasionalmente, não interpretando, visto que a gestualidade e performance corporal dos atores contribuem para a construção de sentidos pelos interlocutores surdos. Assim, os tradutoresintérpretes não expressam, em sinais, todas as palavras, posto que é mais importante transmitir a história geral. Isso permite que o público siga não apenas a interpretação da língua de sinais, mas também a ação no palco.

Assim, o tradutor-intérprete não deve ater-se apenas ao roteiro, texto a ser traduzido, mas também a toda a posiçấo de palco e cenas recorrentes da peça. 
Existem certas semelhanças entre o trabalho preparatório de intérpretes simultâneos e de teatro de língua de sinais (e, nesse caso, com o de descritores de áudio): eles trabalham com o texto escrito e a palavra falada, bem como na compreensão e na conscientizaçáo da improvisação de palco pelos atores, combinando preparação e espontaneidade (SIBUL, 2019, s. p.).

No caso analisado, mesmo que em posição inicial ao lado no palco, o tradutor-intérprete se movimenta e interage com os personagens da história. Constatamos que o tradutor-intérprete não transmitiu informaçóes que são obviamente demonstradas pela ação dos atores no palco. Isso tomaria muito tempo, principalmente, quando há diferentes atores atuando ao mesmo tempo. Então, é preciso coordenar todas as falas, por vezes, sobrepostas, e o que de fato será sinalizado.

\section{e) Iluminação para o tradutor-intérprete}

Como dito anteriormente, por questôes de economia de esforço físico, a direção do espetáculo optou por deixar o canto direito, na perspectiva do público, reservado para o intérprete com uma iluminaçáo de palco fixa neste local, como idealizado pela iluminadora Iscarlat Lemes. Essa iluminação tinha tom quente, a fim de realçar e dar contraste ao figurino e maquiagem do intérprete. Nos momentos de movimentação no palco, essa iluminação apagava e dava lugar a outra iluminação, quente de igual forma, apenas para demonstrar a movimentaçáo no palco. Como apresentado nas figuras 8 e 9, o intérprete tem uma iluminação específica em LED azul que possui diversas configuraçóes, podendo ser piscantes ou uma iluminaçáo única, esmaecendo. Optamos por esta última, pois, nas cenas de blackout completo, ela permanecia acesa para que os surdos pudessem observar os sinais produzidos pelo tradutor-intérprete. 


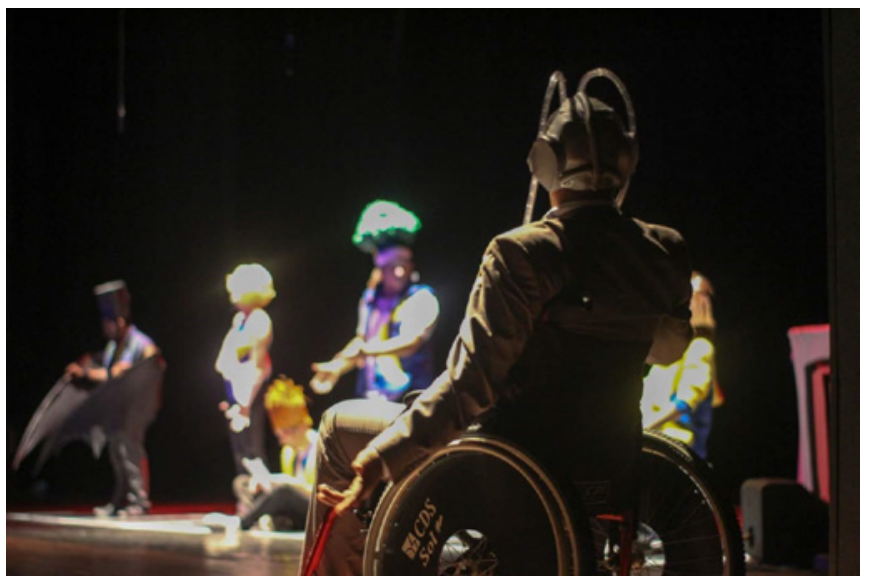

Figura 8: Iluminação projetada no tradutor-intérprete

Fonte: Acervo pessoal dos autores

Fotografia de Rodrigo Sambaqui (crédito)

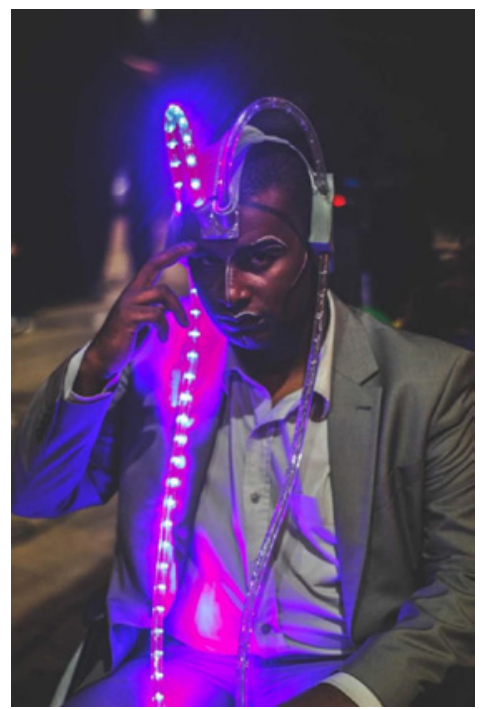

Figura 9: Iluminação do capacete do tradutor-intérprete

Fonte: Acervo pessoal dos autores

Fotografia de Rodrigo Sambaqui (crédito) 
Considerando que os intérpretes de línguas de sinais são visíveis e precisam estar perceptualmente em destaque. Eles precisam ser vistos para serem 'ouvidos' pelos sinalizantes e, além disso, ao trabalhar de uma língua de sinais para uma língua vocal-auditiva, o intérprete deve ser audível para garantir que seu público ouvinte possa ouvir a interpretação do que a pessoa surda está sinalizando (BAKER; SALDANHA, 2009, p. 275).

Nesse sentido, o projeto da peça analisada preocupou-se com a iluminaçáo do tradutor-intérprete, mesmo em momentos de blackout completo, pois havia uma iluminaçáo acoplada a ele, compondo o figurino ao mesmo tempo em que iluminava o corpo para a expressáo em Libras. Assim, concordamos que as escolhas linguístico-discursivas são ideológicas e a posição do sujeito em qualquer interação é singular. "O ato responsável é precisamente o ato baseado no reconhecimento desta obrigatória singularidade. É essa afirmação do meu não álibi no existir que constitui a base da existência" (BAKHTIN, 2010, p. 99). Nessa perspectiva, o ser intérprete, em sua posição ativa-responsiva, é responsável por seus atos na vida, tanto pelo que vive com a linguagem como com as concepçóes que envolvem sua atividade.

\section{Concluindo e apontando para direçóes futuras}

Este artigo, ao apresentar a análise da articulação entre a dimensão linguística e as múltiplas semioses que compóem uma peça teatral, com tradução-interpretação para a Libras, procurou contribuir com a compreensão sobre a tarefa desse profissional na esfera artístico-cultural, sobre a construçáo de sentidos possíveis de artefatos usados em peças teatrais, pelo tradutor-intérprete de Libras-Português, tais como: o figurino, a maquiagem e o foco de luz.

Se estudos da tradução contam com longa e respeitável tradição de análise linguística, restringindo-se à tradução verbal, os estudos da interpretação, por sua vez, náo podem se furtar de problematizar as múltiplas linguagens que envolvem interaçóes sociais. Pesquisa igualmente rigorosa engloba a produção social, cultural e discursiva, assim sendo, o objetivo aqui foi focalizar o musical: X-QUEM? (Mutante Cia de Teatro), de 2019, desde o planejamento do projeto à sua execuçáo. Evidenciamos o papel ativo do TILSP na construção do tradutor como um personagem que desenvolve uma performance específica, desenhada para o espetáculo. 
Concluímos que no gênero peça teatral, advindo da esfera artísticocultural, há a articulação entre a linguagem verbal e a linguagem visual. Respondendo a questōes levantadas na introdução deste trabalho, sobre a mediação do texto de partida e o texto performático, como também sobre os aspectos envolvidos na apresentação no palco, descrevemos como o tradutor-intérprete constrói não só o projeto discursivo, mas também a natureza ideológica e estética do seu discurso, promovendo novas tarefas para esse profissional, a fim de construir uma performance com qualidade. Constatamos que o TILSP, neste caso, assume a cena como um personagem e como tradutor-intérprete, de forma concomitante, integrando a obra. Descrevemos o processo de criação do figurino, maquiagem e posiçãointeração no palco.

Como recomendação para futuras pesquisas, destacamos a necessidade de investigar junto a autores, diretores e tradutores, outros possíveis motivos que podem explicar o que foi levantado neste estudo, como também o que o público surdo apreende quando da caracterização do tradutor-intérprete.

\section{Referências}

BAKER, M.; SALDANHA, G. Routledge Encyclopedia of Translation Studies. Routledge, New York, 2009.

BAKHTIN, M. (VOLOCHÍNOV, V. N.). A interação verbal. In: BAKHTIN, M. (VOLOCHÍNOV, V. N.). Marxismo e filosofia da Linguagem. Problemas fundamentais do método sociológico na ciência da linguagem. Trad. Michel Lahud e Yara F. Vieria. 8a ed. São Paulo: HUCITEC, 1997, p. 110-127.

. Marxismo e filosofia da linguagem: problemas fundamentais do método sociológico na ciência da linguagem. São Paulo: Editora 34, 2016. . Dialogic origin and dialogic pedagogic of grammar. In: Journal of Russian and East European Psychology, v. 42 (Issue 6): 12-49, nov/dez, 2004. Disponível em: <https://www.tandfonline.com/doi/abs/10.1080/10 610405.2004.11059233 >. Acesso em: 28 abr. 2020.

. Para uma filosofia do ato responsável. Tradução de Valdemir Miotello e Carlos Faraco. São Carlos: Pedro \& João Editores, 2010d [1920-24]. BRAIT, B. (Org.). Bakhtin: outros conceitos-chave. 2. ed. São Paulo: Contexto, 2012. 
BRASIL. Lei no 13.146, de 06 de julho de 2015. Institui a Lei Brasileira de Inclusáo da Pessoa com Deficiência (Estatuto da Pessoa com Deficiência). Diário Oficial da República Federativa do Brasil. Brasília: DF. Disponível em: <http://www.planalto.gov.br/CCIVIL 03/ Ato20152018/2015/Lei/L13146.htm>. Acesso em 28 mai. 2018.

FELÍCIO, M. D. O que é importante para uma interpretação simultânea em língua de sinais no contexto artístico? Belas Infiéis, 4(3), p. 33-48. 2016. Disponível em: <https://periodicos.unb.br/index.php/belasinfieis/ article/view/11348>. Acesso em: 28 abr. 2020.

FRISHBERG, N. Interpreting: An Introduction, rev. edn, Silver Spring, MD: RID Publications. 1990.

FOMIN, C. F. R. Interpretaçáo do português para libras no teatro: um olhar para a compreensão de espectadores surdos. Doutorado em andamento em Linguística Aplicada e Estudos da Linguagem. 2018a. Dissertação. (Mestrado) - Pontifícia Universidade Católica de São Paulo, São Paulo. Disponível em: <https://tede2.pucsp.br/handle/handle/21782>. Acesso em: 28 abr. 2020.

Verbo-visualidade e seus efeitos na interpretação em Libras no teatro. Bakhtiniana. Revista de Estudos do Discurso, [S.l.], v. 13, n. 3, p. Port. 142-164 / Eng. 148-170, set. 2018b. ISSN 2176-4573. Disponível em: <http://revistas.pucsp.br/bakhtiniana/article/view/35806 >. Acesso em: 28 abr. 2020.

. Educação e Cultura: experiências de tradução e de interpretação de açôes educativas em instituições culturais. Palestra II Colóquio Internacional Educaçáo de Surdos, Libras e Interpretaçáo - CIELSI. 17 e 18 de outubro de 2019. Florianópolis: UFSC, 2019.

GANZ HORWITZ, M. Demands and Strategies of Interpreting a Theatrical Performance into American Sign Language. Journal of Interpretation, v. 23. Iss. 1, Article 4. Available at: http://digitalcommons.unf.edu/ joi/vol23/iss1/4. 2014. Disponível em: <https://digitalcommons.unf.edu/ cgi/viewcontent.cgi?article=1033\&context=joi $>$. Acesso em: 28 abr. 2020.

HÜLLER, A. Roteiro "X-QUEM? - Origens". Universidade Estadual de Santa Catarina (UDESC), 2019.

. Educação e Cultura: experiências de tradução e de interpretação de açôes educativas em instituições culturais. Palestra II Colóquio Internacional Educaçáo de Surdos, Libras e Interpretaçáo - CIELSI. 17 e 18 de outubro de 2019. Florianópolis: UFSC, 2019. 
INFORME FLORIPA. X-QUEM? - Origens faz no dia 27 a segunda apresentação gratuita em Florianópolis. Disponível em: <http://www. informefloripa.com/2019/08/26/x-quem-origens-faz-no-dia-27-a-segunda-apresentacao-gratuita-em-florianopolis/>. Acesso em: 24 jun. 2020.

LICHTENSTEIN, R. F. Roy Lichtenstein Foundation. Disponível em: $<$ https://lichtensteinfoundation.org/biography/.>. Acesso em: 24 jun. 2020. LUCENA, C. Beijo de Línguas - quando o poeta surdo e o poeta ouvinte se encontram. 154f. Dissertação (Mestrado) - Programa de Pós-graduação em Psicologia Clínica, Pontifícia Universidade Católica de São Paulo, São Paulo, 2017. Disponível em: <https://tede2.pucsp.br/handle/handle/20478 $>$ Acesso em: 10 set. 2019.

PÖCHHACKER, F. Introducing Interpreting Studies. London/New York: Routledge. 2004.

. The Routledge Encyclopedia of Interpreting Studies. by Routledge, New York, 2015.

RICHARDSON, M. Theatrical Interpreting: Providing Accessibility or Policing the Deaf - Hearing Border? In: University of Stirling Arts and Humanities Postgraduate Conference. 3 June 2016. Disponível em: $<\underline{\text { https:// }}$ ahpgconf2016.files.wordpress.com/2016/06/richardson michael theatrical-interpreting.pdf $>$. Acesso em: 28 abr. 2020.

RIGO, N. S. Traduçáo de cançóes de LP para LSB: identificando e comparando recursos tradutórios empregados por sinalizantes surdos e ouvintes. Dissertaçáo (mestrado) - Universidade Federal de Santa Catarina, Centro de Comunicação e Expressão, Programa de Pós-Graduação em Estudos da Tradução, Florianópolis, 2013. Disponível em: <https://repositorio.ufsc.br/ xmlui/handle/123456789/122839?show=full >. Acesso em: 28 abr. 2020.

. Tradução-interpretação teatral: desafios e soluçôes em "O Som das Cores". In: Congresso Nacional de Pesquisas em Traduçáo e Interpretaçáo de Libras e Língua Portuguesa, 4., 2014, Florianópolis. Anais eletrônicos... Florianópolis: UFSC, 2014. Disponível em: <http://www.congressotils.com.br/anais/2014/3071.pdf >. Acesso em: 28 abr. 2020.

SIBUL, K. The Core of Interlingual Simultaneous Theatre Interpreting. Speaker In: CONFERENCE Media for All 8. 20 May 2019. University of Tartu (Finland). Disponível em: <https://www.tolk.su.se/english/media-for-all-8/programme/abstracts/the-core-of-interlingual-simultaneous-theatre-interpreting-1.424584>. Acesso em: 28 abr. 2020.

SILVA NETO, V. S. da. A formaçáo de tradutores de teatro para Libras: 
questóes e propostas. 2017. 121 p. Dissertação (Mestrado) - Programa de Pós-graduação em Estudos da Tradução, Universidade de Brasília, Brasília, 2017. Disponível em: <http://repositorio.unb.br/handle/10482/31266.> Acesso em: 31 mai. 2019.

SILVEIRA, N. M. B. Automaquiagem como exercício cênico. Trabalho de Conclusão de Curso. Licenciatura em Artes Cênicas. Universidade de Brasília. Brasília - DF 2016. Orientador: Prof. Dr. Jorge das Graças Veloso. Disponível em: <http://bdm.unb.br/bitstream/10483/13162/1/2016_NataliaMaiaBrazSilveira.pdf>. Acesso em: 28 abr. 2020.

SOBRAL, A. Da valoração intralinguística à transposição tradutória: uma perspectiva bakhtiana. Cadernos de Traduçáo, Porto Alegre, Número Especial, 2018. Disponível em: <https://seer.ufrgs.br/cadernosdetraducao/article/view/98461/54987>. Acesso em: 28 abr. 2020.

YIN, R. K. Estudo de caso: planejamento e métodos 4a ed. Porto Alegre: Bookman. 2010. 